\title{
Problem-Based Learning in Programming Lesson
}

\section{Achmad Aliyil Khakim}

Faculty of Psychology, Universitas Airlangga, Surabaya, East Java, Indonesia

*Corresponding author:

Achmad Aliyil Khakim

Faculty of Psychology

Universitas Airlangga

Kampus B UNAIR - Jl. Airlangga 4-6

Surabaya, East Java 60286 - Indonesia

Tel.: +62 $315032770 / 5014460$

Email address: achmad.aliyil.khakim-2017@psikologi.unair.ac.id 


\title{
Problem-Based Learning in Programming Lesson
}

\begin{abstract}
Problem-based learning (PBL) is an important practice that provides suitable learning environments for learners through which they acquire complex problem-solving skills (PSS) by working with real-life problem situations (Efendioglu, 2015). Problems push people to think creatively, efficiently, and effectively. Programming skills are needed in this digital era. Programming learning covers the following domains: a) cognitive domain, student understanding, and knowledge analysis, b) affective domain, student assessment and organizing knowledge, and c) psychomotor domain, student skills. Student needs many skills in this digital era, especially problem solving. Students are given opportunities to solve problems in a collaborative setting, create mental models for learning, and configure self-directed learning habits through practice and reflection. Many ways of learning are directed to PBL, such as using a practice experiment module. A module has several purposes: clarify and facilitate the presentation of messages, b) overcome the limitations of time, space, and sensory power for both learners and teachers, c) improve motivation and passion for learning as well as develop the ability to interact directly with the environment and other learning resources that enable learn independent learning, and d) allow learners to measure or evaluate their learning results. First chapter of module contains three experiments' steps that followed by students to understand the lesson. Next chapter contains complex problems based on experiments in first chapter. This study aims to determine the differences in the results of learning between a class that employs PBL method and those that do not. The study employed a comparative experimental quantitative research method. The subjects included 35 students in an experiment group and 35 students in a control group at SMK Negeri 2 Surabaya. To determine the learning results difference between the experimental and control groups, pre- and post-tests were conducted. The Independent Sample T-Test was performed to determine the differences in learning. The results indicate that there were significant learning results differences; employing the method of PBL produced better results than conventional methods. This study can be a reference for teachers to enhance students' PSS through PBL; moreover, it contributes a foundation for future research in developing PSS for students.
\end{abstract}

Keywords: Problem-Based Learning, Module, Learning Results

\section{Introduction}

Indonesia has a 12-year compulsory education program, which means that every Indonesian citizen must have at least 12 years of formal education. In relation to government secondary education, PP No. 19 of 2016 notes that Indonesia Smart Program is a government effort to support the implementation of general secondary education to ensure all citizens receive 12 years of education.

According to data from the 2017 Directorate APBN Preparation, the number of APK and APM reached $88.1 \%$ and $63.4 \%$, respectively. In 2018, the number of APK and APM increased to $89.7 \%$ and $65.3 \%$, respectively. 
Whether education is formal or non-formal, it can be conducted anywhere. School, as an example of formal education, is where teaching and learning activities are conducted. Merlion (2017) asserted that the government must not only guarantee the nation's children 12 years of education, but also must ensure there are no more excessive levies at school. The APBN's budget of $20 \%$ appears to be enough to revolutionize all neglected education sectors and thus, students' parents need not be burdened.

The 12-year compulsory education program is funded by the APBN. The government's hopes to achieve a good output means that if the increase in student learning results are satisfactory they will be able to realize the ideals of "intellectualizing the life of the nation" contained in UUD 1945.

According to Susanto (2013), learning results in a change of students' ability, and involves cognitive, affective, and psychomotor aspects. The results of learning can also be interpreted as the students' achievement level in learning subjects in school and be symbolized as the scores obtained in tests.

The interview results in April with two teachers and one student who was majoring in AV at SMK Negeri 2 Surabaya about the conditions of teaching and learning in programming engineering in class $\mathrm{X}$ revealed the following. As a result of the new curriculum and subjects, the new learning material had to be developed in a limited time. Consequently, some teachers may experience various obstacles such as incomplete modules and no practicum job sheet. Accordingly, the researcher wanted to assist in solving these obstacles; the teachers experienced the learning module that was developed contained problems related to improving students' ability in programming. This module was expected to help and facilitate students in understanding and mastering the programming technique material in the basic competencies of implementing basic programming languages so as to improve the learning results of students. Furthermore, this module contained several problems that would be solved by students in groups employing problem-based learning (PBL).

Accordingly, the researcher was interested in conducting experiments using PBL. The purpose of this study was to determine if there were any differences in the results of those who used PBL and those that do not. It was expected that this study would be a guide to using effective learning models in schools.

\section{Theory}

\section{A. Learning Results}

Sudjana (2009) defined student learning results as changes in cognitive, affective, and psychomotor behavior as a result of learning in a broader sense. Hamalik (2009) noted that proof that someone has learned is when aspects of their behavior change from a position of not knowing to knowing, and not understanding to understanding. Behavior is 
comprised of subjective and motor elements. The results of learning are evident when there is a change in these aspects.

\section{B. $P B L$}

Barrows (1984) describes Problem-Based Learning (PBL), in its purest form, for basic sciences in the medical domain. This involves a three-phase cycle process: Students face problems; students develop professional reasoning skills, and learning needs are identified and regulated by tutors; and a phase of independent study. The cycle is completed by the cooperative phase: Applying newly acquired knowledge to the problem and summarizing what has been learned. The next cycle starts with a new problem. Three main objectives for education are being addressed concurrently: The acquisition of knowledge that has been obtained and can be used as a basis to build new knowledge that will be acquired; the acquisition of skills to extend and improve one's own knowledge that continues to be developed; and the acquisition of professional problem-solving skills (PSS).

Students are challenged by the reasoning skills required by the problem. Furthermore, they are expected to and focus on the learning process. Although teaching seems to be an efficient and easy way to impart knowledge to students, it does not consider each student's ability to absorb that information and benefit students in the future. It is not sufficient to give attention only to students who have reasoning skills or have the ability to learn skills by themselves.

Van Woerden (1991) noted cultural differences of different domains. In engineering education, there are similarities in technical-organizational aspects of the group process whereas in social education, similarities can be found in social-emotional aspects. While social-emotional aspects have an important role in project work and PBL, technicalorganizational aspects are imperative in project work. This makes project work more attractive to people from the engineering domain.

Ramsden (1991) made reference to cultural differences in the teaching styles of various domains in a number of studies. He stated that educational institutions prefer to use formal and didactic teaching methods, and noted less attention is given to suitable learning methods for particular students.

Perrenet (2000) asserted that PBL or project work is relatively difficult to achieve not only in engineering and science domains, but also in medicine. However, this is in contrast to the known popularity of PBL in medical education. PBL is more suitable to reflect a doctor's professional attitude than that of a professional engineer. Various examples have demonstrated that active learning could be successful if implemented in a domain that reflects the reality of the profession. Consequently, in the engineering domain, it is more suitable to use projectbased learning than PBL.

Kilroy (2004) stated that PBL is derived from a theory that students are able to restructure old information they have acquired to gain new knowledge and subsequently, they describe the new information they have acquired. 


\section{Method}

\section{A. Research Design}

Quantitative methods were employed in the study. A comparative experimental quantitative research design was used (Creswell, 2003). Experimental research involves the manipulation of the subjects' conditions. Furthermore, strict control of external factors is applied. In essence, it involves comparative subjects and systematic scientific methods to establish relationships that involve causal phenomena (Arifin, 2009). The independent variable in this study was PBL $(\mathrm{X})$ and the dependent variable was attitude toward learning results (Y) (see Fig. 1).

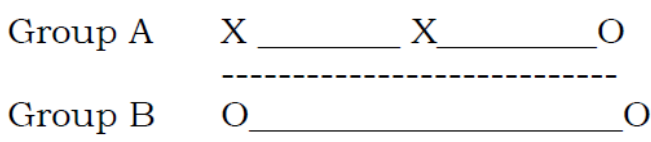

Fig. 1. Research Design

\section{B. Population and Samples}

Sugiyono (2008) noted that population is an object or subject that has specific quantities and characteristics that the researcher wishes to study. The population in this study involved all students of class XI that were majoring in AV at SMK Negeri 2. Purposive sampling, a form non-probability sampling, was employed. Thus, the researcher chose the sample in accordance with the specific criteria of the study and the subjects' willingness to participate in the study (Oliver, 2011). The following criteria were employed to select the sample: First grade in SMK and majoring in $\mathrm{AV}$.

The sample included two of three classes of $X$ that were majoring in AV at SMK Negeri 2. One of the classes formed the experimental group AV-1) and the other the control group (AV2). AV-1 was chosen as the experimental group because this class had a low average while AV-2 was chosen as the control because the class had a high average. There were 35 students in each class; thus, the sample comprised 70 out of 105 students.

\section{Research Instrument and Analysis Technique}

Students in the experimental group were given a module containing several programming algorithm problems that had to be solved so that the algorithm was correct and systematic. One of the problems in the module was that the text on the LCD was written backward, that is, from right to left. The students were required to justify it by ensuring the text on the LCD was written forward, from left to right. In addition, the display of the LED lights had to be regulated if they were not and turned on simultaneously

Pre-test and post-test results from both the experimental group (AV-1) and control group (AV-2) were used. The test questions included practicum procedures and how students develop complicated algorithm programs. The analysis was performed by employing the Independent Sample T-Test with the help of the SPSS 20.0 program. 


\section{Results}

Data collection from the test results (pre-test and post-test) revealed the mean score of the students. The result of the learning was the difference between the pre-test and post-test scores.

Table I. Learning Results

\begin{tabular}{|l|r|r|} 
& Experiment & Control \\
\hline X Pre & 71.92 & 77.95 \\
\hline X Post & 75.90 & 78.97 \\
\hline LR & 3.98 & 1.02 \\
\hline
\end{tabular}

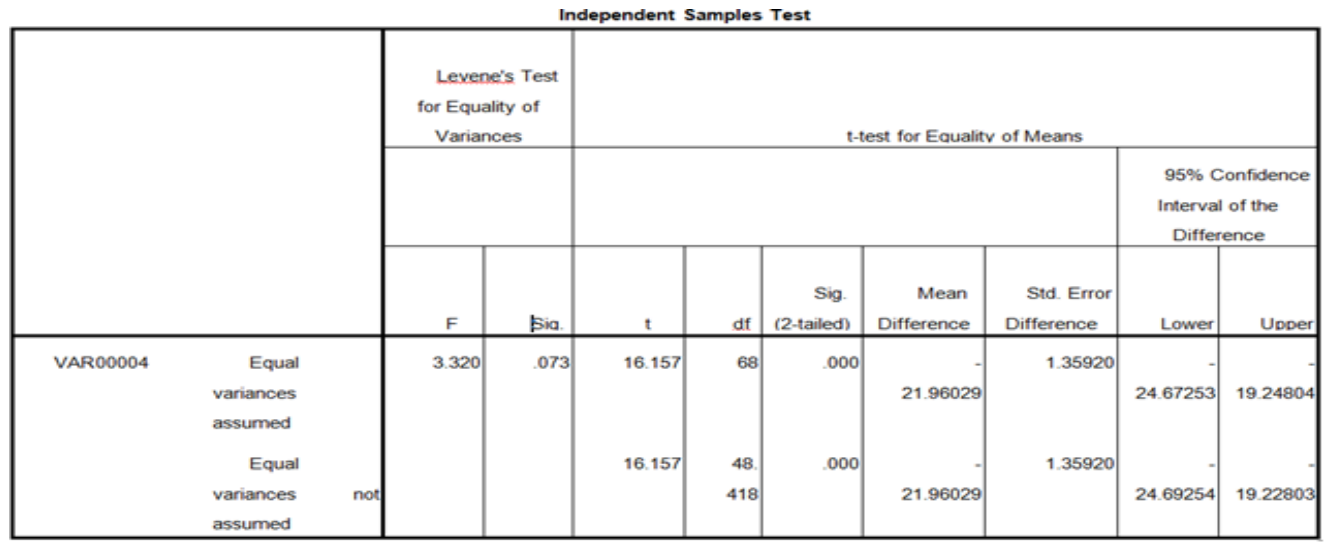

Fig. 2. Hypothesis Test Result

Table 1 shows that the mean scores of the pre-test and post-test in the control group was 77.95 and 78.97, respectively, demonstrating that the mean score of learning results in the control class was 1.02. On the contrary, the mean scores of the pre-test and post-test in the experimental group was 71.92 and 75.90 , respectively, showing the mean score of the learning results was 3.98.

Subsequently, a hypothesis test employing the Independent Sample T-Test was conducted. The results of the hypothesis test revealed $t=16.157$. In this study, the 35 students in each group had a $68 \%$ degree of freedom so that a arge $t_{\text {table }} 2.01$ thus $t_{\text {count }}>$ large $t_{\text {table }}$ high. Furthermore, the significance level was less than 0.05. Consequently, the hypothesis was rejected.

The results of this analysis revealed the learning results differences between the students of the experimental group (AV-1) and control group (AV-2).

\section{Discussion}

The results of this study indicate that cognitive skills as well as skills for designing map concepts when developing programs are needed by students. Class learning that employs PBL improves students' abilities in programming. 
The learning results in the experimental group and control group were 3.98 and 1.02, respectively. These results suggest that using PBL produces better learning results.

The PBL curriculum changes applied to the graduation class in 1997 demonstrated better performance results on USMLEs and an increase in evaluation from the director of the residency program. This change was expected to equip graduates with the knowledge and skills needed to practice in a complex health care system. The results report could lead to investment in financial and human resources for the development of our PBL curriculum (Hoffman, 2006).

The mean scores of six of the nine comparisons for USMLE were significantly higher ( $\mathrm{p}$ $<0.01)$ for UMCSOM PBL students than for students who had taken the national exam for the first time. This difference could not be used as a reference because the test participants had various abilities such as academic ability, increased assignment time, and/or a small class. The increase in continued performance became a habit as demonstrated by the program director's perception of the superior performance of UMCSOM PBL graduates (Hoffman, 2006).

The results of this study demonstrate that students need cognitive skills as well as the ability to map concepts when developing programs. Class learning that employs PBL in a class environment was expected to improve students' abilities in programming. PBL and concept mapping proved to be a complementary. This complementary form of knowledge was visualized in the form of a concept map consisting of methods of collecting information, formulating hypotheses, and identifying problems. Thus, it could be used as a cognitive framework of meaningful learning applied to each case in the whole course (Rendas, 2006).

Although increasing professional PSS was very important in engineering education PBL was not enough and had to be supplemented by providing problem-solving activities in a small and large time-scale. Smaller problems were more suitable for individual tasks and/or interactive quizzes and focus group discussions guided by the teacher. PBL was not used as a main strategy, especially to demonstrate application in the early stages of the curriculum. Project work was more suitable in learning to solve engineering problems, because a longer time-scale and various project work activities adequately map reality (Perrenet, 2000).

\section{Conclusion}

The results of this study reveal that there are significant learning results differences in PBL (AV-1 as experimental group) and conventional learning (AV-2 as control group) indicated by the rejected $\mathrm{H}_{0}$. Thus, there were differences in the results between the students in the experimental group and those in the control group in the programming lesson.

The results of this study are expected to be a reference for teachers who wish to apply it at school. It is recommended that further studies be conducted to develop students' PSS. 
This study was limited in that not enough problems were given to the students; the more problems they are given, the better their level of problem-solving will be.

\section{References}

Arifin, Z. (2009). Metodologi Penelitian Pendidikan. Surabaya: Lentera Cendikia.

Creswell, J. W. (2003). Research design qualitative, quantitative and mixed methods approaches. London: Sage Publications Ltd.

Direktorat. Penyusunan APBN 2018. Informasi APBN 2018.

Efendioglu, A. (2015). Problem-based learning environment in basic computer course: Pre-service teachers' achievement and key factors for learning. Journal of International Education Research, 11(3), 205-216.

Hamalik, O. (2009). Proses Belajar Mengajar. Jakarta: PT Bumi Aksara.

Hoffman, K. (2006). Problem-based learning outcomes: Ten years of experience at the university of missouriColumbia School of Medicine. Missouri: Academic Medicine.

Kilroy, D. A. (2004). Problem based learning. Retrieved from Emjonline.com.

Mendikbud. (2016). Peraturan Menteri Pendidikan dan Kebudayaan Republik Indonesia Nomor 19 Tahun 2016. Jakarta.

Merlion, M. I. (2017). Pelaksanaan Program Wajib Belajar 12 Tahun di Kota Pekanbaru. JOM FISIP, 4(1).

Oliver, P. (2011). Purposive sampling. London: SAGE Publications, Ltd.

Perrenet, J. C. (2000). The suitability of problem-based learning for engineering education: Theory and practice. Teaching in higher education, 5(3), 345-358.

Ramsden, P. (1991). Context and strategy; situational influences on learning. In R.R. SCHMECK (Ed.) Learning Strategies and Learning Styles. New York: Plenum Press.

Rendas, A. B. (2006). Toward meaningful learning in undergraduate medical education using concept maps in a PBL pathophysiology course. American Physiological Society.

Sudjana, N. (2012). Penilaian Hasil Proses Belajar Mengajar. Bandung: PT. Remaja Rosdakarya.

Sugiyono. (2011). Metode Penelitian Kombinasi. Bandung: Alfabeta

Susanto, A. (2013). Teori Belajar dan Pembelajaran di Sekolah Dasar. Jakarta: Kencana Prenadamedia Group Undang-Undang Dasar 1945 (versi amandemen)

Woerden, W. V. (1991). Het projectonderwijs onderzocht [Research on the project method of teaching] (Master thesis). University of Twente, Enschede, Netherland. 